\title{
USP7 wt Allele
}

National Cancer Institute

\section{Source}

National Cancer Institute. USP7 wt Allele. NCI Thesaurus. Code C118238.

Human USP7 wild-type allele is located in the vicinity of $16 \mathrm{p} 13.3$ and is approximately 72

$\mathrm{kb}$ in length. This allele, which encodes ubiquitin carboxyl-terminal hydrolase 7 protein, plays a role in the deubiquitination of other proteins. 